Vol. 3, No. 2, Juli 2019, 57-66

Available Online at https://ejournal.warmadewa.ac.id/index.php/kulturistik DOI: dx.doi.org/10.22225/kulturistik.3.2.1194

\title{
CARA-CARA NICA MEMPENGARUHI RAKYAT SUPA- YA TIDAK BERSIMPATI KEPADA PARA PEJUANG PA- DA MASA REVOLUSI FISIK DI BALI 1945-1950
}

\author{
Ida Bagus Astika Pidada \\ Universitas Warmadewa \\ astikapidada@gmail.com
}

\begin{abstract}
ABSTRAK
Menyerahnya tanpa syarat Letnan Jendral H. Ter Pooerten (Panglima Angkatan Perang Hindia Belanda) kepada Letnan Jendral Hitosyi Imamura (Pimpinan Angkatan Perang Jepang ), maka sejak itu pemerintah Hindia Belanda berakhir di Indonesia. Tidak beberapa lama Jepang berkuasa di Indonesia, maka pada tanggal 15 Agustus 1945 menyerah tanpa syarat kepada Sekutu. Selanjutnya pada tanggal 2 Maret 1946 Brigade Y mulai didaratkan sepanjang pantai Sanur. Brigade Y ini dijuluki "Gajah Merah". Mendaratnya Gajah Merah di Bali, situasi menjadi tidak aman. Kedatangan Belanda (NICA) tersebut mendapat perlawanan dari para pejuang di Bali di bawah pimpinan Letnan Kolonel I Gusti Ngurah Rai. Untuk mendapat simpati dari rakyat Belanda menggunakan berbagai macam cara mempengaruhi. Belanda (NICA) mempengaruhi rakyat dengan 2 cara yaitu dengan cara lunak dan cara kekerasan. Dengan cara lunak Belanda (NICA) memberi materi kepada rakyat seperti : memberi rokok, jajan, uang, kain batik, nasi dan jalan - jalan naik mobil. Dalam memberi bantuan lunak Belanda juga memanfaatkan kaki tangannya seperti : NICA Gandek, AP dan lain - lain. Belanda (NICA) dalam hal ini kelihatan baik dan dermawan kepada rakyat sehingga mereka mendapat simpati. Umumnya yang dipengaruhi oleh Belanda masyarakat yang ekonominya kurang mampu dan pendidikannya rendah. Dengan cara kekerasan Belanda sengaja memamerkan pejuang yang ditangkap kepada masyarakat seperti : ditendang, dipukul, diseret dengan mobil, dan ditembak dihadapan rakyat. Cara ini dilakukan kepada daerah - daerah yang pro republik sehingga rakyat menjadi jera dan takut. Melalui cara ini Belanda (NICA) berharap rakyat tidak lagi mau membantu para pejuang. Untuk menjatuhkam mental masyarakat Belanda (NICA) sengaja menelanjangi kaki tangannya atau tentaranya yang terbunuh dalam peperangan yang diarak keliling kota dengan menggunakan mobil truk bak terbuka yang diisukan ada pemuda yang tewas. Bagi ibu - ibu dan bapak - bapak yang terprovokasi proganda Belanda ini menyebabkan jiwanya tergoncang. Inilah cara - cara Belanda mempengaruhi rakyat Bali, namun demikian rakyat Bali dan pejuang tidak tergoyahkan. Terbukti rakyat dan pejuang tetap bersatu sehingga revolusi fisik yang terjadi di Bali cukup lama dapat bertahan.
\end{abstract}

Kata kunci: NICA, mempengaruhi, rakyat.

\begin{abstract}
[Title: The Ways of Influencing the People of NICA to Understand at Physical Revolution for Balinese People in Bali 1945-1950] Giving up without the conditions of Lieutenant General H. Ter Pooerten (Commander of the Dutch East Indies) to Lieutenant General Hitosyi Imamura (Japanese Army Chief), then the Dutch East Indies government has since ended in Indonesia. Not a long time ago Japan ruled in Indonesia, on August $15^{\text {th }}, 1945$ surrendered unconditionally to the allies. Then on March $2^{\text {nd }}, 1946$ the Y Brigade began landed along the Sanur coast. This Y Brigade is nicknamed "Gajah Merah".
\end{abstract}


Vol. 3, No. 2, Juli 2019, 58

Available Online at https://ejournal.warmadewa.ac.id/index.php/kulturistik DOI: dx.doi.org/10.22225/kulturistik.3.2.1194

The arrival of the Gajah Merah in Bali, the situation became unsafe. The arrival of the Dutch (NICA) received resistance from fighters in Bali under the leadership of Lieutenant Colonel I Gusti Ngurah Rai. Sympathy getting from the Dutch people use various ways of influencing. The Dutch (NICA) influences the people in two ways, namely by means of soft and violent methods. In the soft way the Dutch (NICA) gave material to the people such as: giving cigarettes, snacks, money, batik cloth, rice and traveling by car. In providing soft assistance the Dutch also use their accomplices such as: NICA Gandek, AP and others. The Netherlands (NICA) in this case looks good and generous to the people so they get sympathy. Generally, it is influenced by the Dutch, whose economies are poor and whose education is low. By means of violence, the Dutch deliberately exhibited fighters who were captured by the public such as being kicked, beaten, dragged by car, and shot in front of the people. This method is carried out to regions that are pro-republic so that people become deterred and afraid. In this way the Dutch (NICA) hopes that the people will no longer want to help the fighters. To fall on the mentality of the Dutch people (NICA) deliberately stripped their hands or soldiers who were killed in a war that was paraded around the city by using an open truck that was rumored to be a young man who was killed. The mothers and fathers who were provoked by the Dutch propaganda, his soul was shaken. This is the way the Dutch influenced the Balinese people, however, the Balinese people and fighters were not deterred. Evidently the people and fighters remain united so that the physical revolution that took place in Bali can last long enough.

Keywords: NICA, influence, people.

\section{PENDAHULUAN}

Dengan menyerahnya tanpa syarat Letnan Jendral H. Ter Pooerten (Panglima Angkatan Perang Hindia Belanda) atas nama Angkatan Perang Serikat di Indonesia kepada Letnan Jendral Hitosy Imamura (Pimpinan Angkatan Perang Jepang) yang khusus merebut pulau Jawa pada tanggal 8 Maret 1942, maka sejak saat itu pemerintah Hindia Belanda berakhir di Indonesia (Kartodirdjo \& dkk., 1977: 5). Pada waktu itu Hindia Belanda termasuk persekutuan ABCD (Amerika, Britain, China and Duth) sehingga Jepang perlu menguasainya. Dalam hal ini termasuk serdadu Belanda menjadi tawanan Jepang, karena tidak sempat lari ke Australia seperti KNIL, Mariane dan lain - lain. Para tawanan ini dikirim ke pedalaman yaitu perbatasan Birma dan Siam. Adapun tugas tawanan ini membuka hutan belantara dalam rangka membuat jalan kereta api dan jembatan untuk menembus perbatasan dari negara Siam ke negara tetangganya dengan membuat jembatan. Jembatan tersebut terkenal bernama "The Brigde Over Kwai" yang banyak memakan korban seperti : kecelakaan, sakit, serta ada yang mati kelaparan (Pendit, 1979: 140).

Tidak beberapa lama Jepang berkuasa di Indonesia pada tanggal 15 Agustus 1945 Jepang menyerah tanpa syarat kepada Sekutu. Penyerahan ini diakhiri dengan penanda tanganan di atas geladak kapal perang Amerika "Missouri" tanggal 2 September 1945 (Kansil \& (dkk.), n.d.: 43). Kalahnya Jepang timbul keinginan orang - orang Belanda untuk kembali ke Hindia Belanda. Mereka mulai mengadakan latihan dalam waktu singkat untuk persiapan ke Hindia Belanda (Indonesia). Sebagai panglima Sekutu untuk Asia Tenggara yaitu Mac Arthur. Untuk Asia Tenggara Mac Arthur menyerahkan tugas kepada Laksamana Lord Louis Mounbatten. Lord Louis Mounbatten membagi tugas pendaratan ini menjadi 3 antara lain : Malaya, Saigon, dan Indonesia. 
Di Indonesia pembagian pendaratan dibagi 2 (dua) antara lain : (1) Kalimantan, Indonesia Timur, dan Nusa Tenggara ditugaskan kepada pasukan Australia, (2) Sumatera, Jawa, Bali, dan Lombok ditugaskan kepada pasukan Inggris (Tirtoprodjo, 1963: 13). Melalui pasukan Inggris pegawai - pegawai sipil Belanda bisa diperbantukan dengan kedok sebagai pegawai NICA. Belanda menyelundupkan orang - orang militer ke Indonesia (Tirtoprodjo, 1963: 14).

Selanjutnya pada tanggal 2 Maret 1946 rombongan pertama Brigade Y mulai di daratkan sepanjang pantai Sanur (di sebelah tenggara kota Denpasar). Brigade Y ini dijuluki "Gajah Merah". Gajah Merah didaratkan di Bali dan Lombok. Di Bali Gajah Merah yang didaratkan yakni batalyon 10 dan 11 di bawah Komando Letkol Ter Meulen dan Letkol Pieter Camp. Setelah mendarat mereka langsung mulai gerakannya sebagai berikut : (1) Tanggal 2 Maret 1946 menduduki Denpasar, (2) Tanggal 3 Maret 1946 menduduki Gianyar, (3) Tanggal 5 Maret 1946 menduduki Singaraja, (4) Tanggal 7 Maret 1946 menduduki Tabanan, Klungkung, Bangli, dan Karangasem, (5) Tanggal 13 Maret 1946 menduduki Negara. Dalam hal ini pulau Bali oleh Belanda dibagi atas 3 komando daerah militer yaitu : Gianyar, Denpasar, dipegang oleh Kapten Cassa. Kemudian Letnan Groet menguasai Klungkung, Bangli, dan Karangasem. Sedangkan Kapten Ter Wilde menguasai Tabanan, Negara, dan Singaraja (Hardjawiganda \& (dkk.)., 1982: 48 - 49). Mendaratnya Gajah Merah di Bali, situasi menjadi tidak aman. Atas dasar itu Belanda menarik 3 kompi lagi pasukan Gajah Merah yang ada di Lombok.

Para pemuda pejuang baru mengetahui bahwa yang sebenarnya mengaku tentara Sekutu itu tidak lain adalah tentara NICA (Belanda) yang ingin berkuasa kembali di Indonesia khususnya Bali (Pendit, 1979: 144). Kedatangan NICA (Belanda) tersebut pada akhirnya mendapat perlawanan dari para pejuang di Bali yang dipimpin oleh Letnan Kolonel I Gusti Ngurah Rai. Para pejuang melawan NICA (Belanda) tidak mengenal lelah mereka terus bertempur tidak henti hentinya. Untuk mendapat simpati rakyat, NICA (Belanda) menggunakan berbagai macam pengaruh supaya rakyat tidak bersimpati kepada para pejuang.

\section{PEMBAHASAN}

Mempengaruhi diartikan sesuatu yang timbul dari orang yang berkuasa atau berkekuatan untuk memberikan pengaruh (Poerwadarminta, 1976: 731). Sedangkan simpati menurut dalam hal ini diartikan menaruh kasih atau belas kasihan (Poerwadarminta, 1976: 449 - 948).

Demikian halnya dengan pengertian revolusi ada beberapa pendapat para ahli antara lain : A.H. Nasution, Sartono Kartodirdjo maupun I Nyoman Dekker. Revolusi adalah meruntuhkan sistem - sistem lama (Nasution,A, 1977: 243). Lain halnya dengan pendapat Sartono Kartodirdjo, revolusi tidak lain suatu proses politik yang timbul pada situasi kritis dimana golongan - golongan yang konflik mengusahakan perubahan - perubahan politik dengan cara - cara radikal (Kartodirdjo, 1970: 12). Sedangkan menurut I Nyoman Dekker pengertian revolusi yakni perubahan secara cepat sifatnya fundamental terjadi dalam waktu singkat (Dekker, 1980: 13-14).

Begitu halnya pada waktu terjadi revolusi fisik di daerah Bali para pejuang tidak mengenal lelah bahu membahu menghadapi Belanda (NICA) beserta kaki tangannya (antek - anteknya atau mata - matanya) karena tidak sudi dijajah kembali. Belanda (NICA) dalam hal ini menggunakan berbagai macam cara untuk 
mempengaruhi rakyat agar dapat menarik simpati. Selain itu Belanda (NICA) juga menggunakan berbagai macam teror kepada rakyat supaya mereka menjadi takut dan sebaliknya membenci para pejuang. Meskipun demikian Belanda (NICA) tidak mudah dapat mengalahkan para pejuang di Bali, terbukti pada masa revolusi fisik di Bali para pejuang cukup lama dapat bertahan menghadapi Belanda. Belanda dalam hal ini sudah menggunakan peralatan tempur yang jauh lebih modern dengan tentara yang terlatih dibandingkan para pejuang namun tidak mudah dapat mengalahkannya.

Sedangkan batasan waktu yang digunakan dalam tulisan ini meliputi tahun 1945 - 1950. Tahun 1945 digunakan sebagai batasan awal dari tulisan ini adalah setelah Proklamasi Kemerdekaan Republik Indonesia, Belanda (NICA) ingin menjajah kembali sehingga perjuangan bangkit kembali. Kemudian tahun 1950 digunakan sebagai batasan akhir dari tulisan ini karena perjuangan di Bali telah berakhir dengan penurunan gerilya berhubung adanya pengakuan kedaulatan.

Pada waktu terjadinya revolusi fisik di Bali berbagai macam cara yang digunakan oleh Belanda (NICA) beserta kaki tangannya untuk mempengaruhi rakyat termasuk menggunakan teror agar tidak bersimpati kepada para pejuang dimana berada antara lain :

-Membagikan jajan, rokok serta menghamburkan uang logam. Cara cara seperti ini pernah dilakukan oleh Belanda (NICA) di daerah Kintamani untuk menarik simpati dari rakyat. Rakyat dalam hal ini menganggap bahwa Belanda adalah orang yang baik dan sangat dermawan. Belanda (NICA) juga berjanji kepada rakyat Kintamani,bahwa dalam waktu yang dekat akan kembali ke daerah ini untuk membawa uang logam sebanyak - banyaknya serta kain batik. Melalui cara - cara ini Belanda (NICA) mempengaruhi rakyat di daerah Kintamani (Pindha, 1964)

-Memberikan roti dan jalan - jalan naik mobil. Kejadian ini pernah dialami oleh I Gusti Ngurah Munang Wirawan dari Taman Punggul, Blahkiuh Badung pada masa kecil dirayu oleh NICA. Adapun maksudnya untuk mengungkap persembunyian ayahnya yang mendapat julukan Pak Sugriwa. NICA memperlakukan I Gusti Ngurah Munang Wirawan dengan cara simpatik. Pada waaktu itu I Gusti Ngurah Munang Wirawan ditemani oleh bibinya sempat mencegahnya sehingga dibentak oleh penguasa NICA yang dibantu kaki tangannya yaitu dari AP. I Gusti Ngurah Munang Wirawan yang menjadi sandera di atas mobil NICA akhirnya tidak berhasil mengungkap persembunyian ayahnya ("Mantan Tawanan Kecil NICA, Munang Yang Kadis LLAJ Bangli," 1991: 1).

-Nasi. Kira - kira jam 08.00 pagi I Gusti Ngurah Pindha bersama kawan kawannya sampailah di desa Blandingan, salah satu desa kecil terletak di daerah ujung timur laut danau Batur. Pada waktu itu diadakan perundingan dengan orang - orang di desa Belandingan untuk mendapatkan sekedar makanan. Rupanya permintaan itu disetujui oleh orang - orang desa tersebut sehingga tersiarlah berita bahwa makanan akan segera diperoleh. Ternyata hingga larut malam makanan yang ditunggu - tunggu tidak kunjung datang. Keesokan harinya pagi pagi benar tanggal 16 Juli 1946 ada pengumuman supaya semua para pejuang bersedia mengambil makanan karena nasi yang ditunggu - tunggu sudah datang. Semua para pejuang mengambil tempurung tempat nasi mereka masing - masing, selanjutnya menuju ke tempat orang - orang yang membagi - bagikan nasi tersebut. I Gusti Ngurah Pindha dalam hal ini orang yang pertama sampai di tempat orang - orang yang membagikan nasi tersebut. Adapun nasi yang dibagikan oleh 
Vol. 3, No. 2, Juli 2019, 61

Available Online at https://ejournal.warmadewa.ac.id/index.php/kulturistik DOI: dx.doi.org/10.22225/kulturistik.3.2.1194

orang - orang desa tersebut hanya satu besek. Diperkirakan nasi tersebut hanya dapat dinikmati untuk 20 orang saja. Pada waktu ini sudah ada kecurigaan dari para pejuang sebelumnya karena melihat dari gerak - gerik orang yang membagikan nasi tersebut seperti gelisah dan mengulur - ulur waktu. Tiba - tiba terdengar suara kapal udara meraung - raung dari arah timur menuju tempat para pejuang berada dimana kapal tersebut langsung melepaskan tembakan 12,7. Akibat serangan kapal udara ini, para pejuang selanjutnya masing - masing melarikan diri mencari perlindungan untuk menghindari gempuran tersebut. Ketika serangan kapal udara berlangsung, I Gusti Ngurah Pindha sempat menoleh kepada orang yang membagikan nasi itu ternyata sudah lari dan menghilang. Orang yang membagikan nasi tadi ternyata adalah penghianat yakni dengan cara memberikan umpan nasi kepada para pejuang oleh NICA melalui kaki tangannya (Pindha, 1968: II).

-Provokasi. Cara ini paling sering digunakan oleh Belanda (NICA) terhadap rakyat maupun para pejuang. Hal ini dilakukan karena Belanda (NICA) tidak mengeluarkan biaya untuk mempengaruhinya serta dapat membuat takut masyarakat. Beberapa bentuk provokasi yang pernah dilakukan oleh Belanda (NICA) seperti di daerah Pengajaran. Belanda pada waktu ini memprovokasi rakyat untuk mengurung pemuda. Rakyat di daerah Pengajaran bersedia mengejar pemuda dengan beberapa alasan antara lain dikatakan sebagai perampok atau penggarong serta pengacau akibat termakan provokasi Belanda. Demikian halnya dengan nasib Ngurah Raka pemuda yang terpisah dari pasukan induk. Ngurah Raka dikagetkan tiba - tiba dengan bunyi suara manusia yang baru berjalan beberapa puluh meter meninggalkan tepi jurang. "Ih Jero, ragane pemuda (Hai saudara, apakah anda pemuda), tepat dihadapan Ngurah Raka telah berdiri seorang manusia berbadan besar, kuat, kekar, dengan memegang sebilah parang besar menatapnya dengan sorotan mata yang amat tajam. Pada waktu ini Ngurah Raka langsung menjawabnya dengan amat lugu, "Inggih tiang pemuda, sapunapi" (Ya saya pemuda, kenapa). "Yan pemuda, lakar juk" (kalau pemuda, saya mau tangkap) kata orang berbadan besar kekar tersebut. "Inggih rarisang, ejuk sampun" (ya saya persilahkan, tangkaplah saya) jawab Ngurah Raka dengan tenang. Pada waktu itu Ngurah Raka tidak membawa senjata. Melihat penampilan Ngurah Raka yang tenang tersebut dan lugu serta menjawab dengan bahasa daerah yang halus dan sopan, ternyata yang dimaksud dengan pemuda tidak diperkirakan sebelumnya sebagai pengacau, perampok atau penggarong oleh Belanda (NICA) adalah tidak benar. Pemuda yang dilihat oleh orang yang berbadan besar kekar sebenarnya mereka adalah orang baik - baik. Orang yang berbadan besar kekar tersebut selanjutnya bertanya lain lagi kepada Ngurah Raka . "Mangkin dumun, tiang metaken ragane pemuda saking dija" (Tunggu dulu, saya mau bertanya saudara pemuda dari mana). "Tiang saking Gerana" (Saya dari Gerana). Orang yang berbadan besar kekar tersebut selanjutnya mendekati Ngurah Raka sambil berbisik "mohon ampun beribu - ribu ampun atas kesalahan saya" Menurut orang yang berbadan besar kekar tersebut sekarang jangan dulu meninggalkan daerah ini, karena serdadu Belanda (NICA) di sekitar ini sangat banyak dan berkeliaran disana - sini. Selanjutnya orang yang berbadan besar kekar tersebut mengajak Ngurah Raka pergi menuju jurang tersebut kembali. Ngurah Raka diajak menuju ke sebuah goa. Bersembunyilah dulu disini kata orang yang berbadan besar kekar tersebut kepada Ngurah Raka sampai serdadu Belanda (NICA) pergi dari daerah ini. Nanti sewaktu - waktu kata orang yang berbadan besar ke- 
Vol. 3, No. 2, Juli 2019, 62

Available Online at https://ejournal.warmadewa.ac.id/index.php/kulturistik DOI: dx.doi.org/10.22225/kulturistik.3.2.1194

kar tersebut saya datang kembali yaitu pada malam hari. Ngurah Raka bersembunyi di goa ini yaitu selama 3 hari 3 malam (Pindha, 1968: II).

Cara lain yang dilakukan oleh Belanda (NICA) mempropokasi rakyat yaitu dengan memamerkan mayat - mayat kaki tangannya yang terbunuh dalam peperangan seperti HP, serdadu sewaan, dan NICA gandek. Mayat - mayat ini sengaja ditelanjangi oleh tentara Belanda (NICA) untuk dipamerkan keliling kepada masyarakat dimana dikatakan itu adalah bangkai pemuda anak buah I Gusti Ngurah Rai yang sudah hancur di bom dan ditembak. Cara - cara licik semacam ini sengaja diciptakan oleh tentara Belanda kepada para ibu - ibu maupun bapak - bapak yang tidak mengetahui taktik ini akan termakan propokasi tersebut sehingga menyebabkan mereka tergoncang jiwanya (Pindha, 1964). Propokasi yang dilakukan oleh Belanda tidak saja kepada kaki tangannya juga kepada para pejuang. Hal ini pernah dilakukan kepada pejuang A. A. Putra. Pada masa revolusi fisik di Bali A.A. Putra menggunakan nama samara "Maruti". Ketika berkunjung ke desa Ringdikit yaitu di sebelah selatan desa Bubunan dengan beberapa pemuda pejuang, A.A. Putra di kepung dari berbagai jurusan oleh tentara militer Belanda (NICA) di desa ini. Hanya dengan berbekal senjata pistol saja ditangannya, A.A. Putra mengadakan perlawanan sengit terhadap tentara militer Belanda. Berhubung senjata api yang dimiliki oleh A.A. Putra tidak seimbang melawan tentara Belanda yang bersenjata lengkap dan modern di sungai disebelah barat desa tersebut, A.A. Putra dengan nama samaran Maruti akhirnya gugur dalam pertempuran tersebut bersama temannya yang bernama Sumpena. Selanjutnya serdadu - serdadu Belanda (NICA) membawa jenasah ini ke Seririt dengan diseret mobil untuk dipertontonkan kepada rakyat. Jenasah A.A. Putra akhirnya dimakamkan oleh masyarakat desa Bubunan di kuburan desa ini ("Mengenang gugurnya pahlawan Maruti," 1986: I). Demikian halnya ketika terjadi puputan Margarana, masyarakat desa Marga diteror oleh Belanda (NICA). Seluruh rakyat di keluarkan dari rumah untuk dikumpulkan di pasar Marga. Pada waktu ini yang dikumpulkan tidak saja anak - anak, orang tua, orang muda dan laki - laki juga orang perempuan. Orang - orang yang dikumpulkan ini tidak saja ditendang oleh tentara Belanda ada pula yang dipukul dan ada beberapa yang ditembak. Belanda (NICA) pada waktu ini sangat marah kepada rakyat karena tidak seorangpun mau membuka mulut tentang keberadaan para pejuang di desa ini (Suralaga, 1982: II). Begitu pula ketika para pejuang kembali setelah pertempuran Tanah Aron, dalam perjalanannya kembali para pejuang melihat laki laki berderet di sepanjang jalan - jalan kecil di desa tersebut. Para laki - laki ini membawa senjata seperti : bambu runcing, sabit besar, tombak dan bandil (ranting - ranting pohon berduri yang panjang). Bandil dipasang dengan cara melingkar di ujung bambu yang garis tengahnya kira - kira setengah meter. Pada waktu itu I Gusti Ngurah Pindha heran melihat orang - orang desa ini, namun pada akhirnya dapat dimengerti karena mereka sebenarnya orang - orang bodoh yang mendapat perintah dari Belanda (NICA) untuk menjaga kampungnya. Orang - orang desa ini mendapat informasi dari Belanda (NICA) bahwa kampungnya akan mendapat gangguan dari para pemuda yang datang. Pemuda - pemuda yang datang tersebut dikatakan bertujuan untuk merampok. Orang - orang desa ini nampaknya seperti ragu - ragu dan tegang karena tidak mengetahui siapakah yang dimaksud dengan para pemuda tersebut. Pada hal pada waktu ini para pejuang sedang lewat di kampungnya. Melihat situasi ini, I Gusti Ngurah Rai selanjutnya menginstruksikan kepada para pejuang "supaya berjalan terus, jangan 
Vol. 3, No. 2, Juli 2019, 63

Available Online at https://ejournal.warmadewa.ac.id/index.php/kulturistik DOI: dx.doi.org/10.22225/kulturistik.3.2.1194

mengganggu orang - orang - orang desa serta jangan masuk ke kampung mereka. Dari belakang perintah di oper ke belakang maupun ke depan. Meskipun begitu karena jumlah pasukan cukup banyak ada pula diantara para pejuang yang tidak disiplin. Para pejuang ini ingin mengetahui apa sebenarnya yang hendak dibuat oleh orang - orang desa ini. "Hai" untuk apa ini , tanya para pejuang dalam bahasa daerah kepada orang - orang desa yang sedang memegang bandil itu. Orang orang desa yang sedang memegang badil itu langsung menjawab "Puniki anggen ngejuk pemuda" (ini dipakai menangkap pemuda). Selanjutnya para pejuang kembali bertanya "kengkenang ngejuk pemuda" (bagaimana cara menangkap pemuda). Lalu dijawab oleh orang - orang desa yang memegang bandil itu "tangkeb antuk puniki" (tangkap dengan benda ini). Ini adalah hal yang lucu dan mengerikan apabila menangkap pemuda dengan bandil. Sebenarnya orang orang desa ini tidak mengetahui siapa sesungguhnya yang diajak berbicara tersebut. I Gusti Ngurah Pindha bergurau sambil berjalan di samping I Gusti Ngurah Rai bahwa Pak Rai hendak ditangkap dengan menggunakan bandil tersebut. I Gusti Ngurah Rai lalu menjawab "Ya kalau kepala kita masuk ke dalam bandil tentu tidak bisa keluar lagi " sambil tertawa. Diantara para pejuang pada waktu itu, ada salah satu anggota pasukan yang membawa sten mengokangnya. Kamu berani menangkapnya, sambil menggertak kepada orang yang membawa bandil itu. Selanjutnya orang - orang desa ini langsung serentak jongkok membuang senjata yang dibawanya. Beberapa diantara orang - orang desa tersebut ada yang mengangkat tangan secara ragu - ragu mengucapkan "Mereka". Dalam hal ini yang diucapkan "Mereka" yang dimaksud oleh orang - orang desa tersebut adalah "Merdeka". Para pejuang yang melihat keadaan lucu ini menjadi tertawa (Pindha, 1968: II). Demikian halnya dengan Wijakusuma dan kawan - kawan ketika sampai di desa Sidan. Desa ini di kurung oleh ratusan tentara Belanda (NICA) beserta ratusan NICA Gandeknya. Di dalam dan di sekeliling desa tersebut penuh oleh orang - orang mereka. Semua halaman yang ada di desa Sidan di tumbuk - tumbuk oleh tentara Belanda (NICA) bersama kaki tangannya dengan sebatang kayu dengan maksud untuk mengetahui apakah ada gua - gua tempat berlindung para pejuang di bawah tanah. Pada waktu ini Wijakusuma dan kawan - kawan berada di jurang sebelah timur desa Sidan. Suara gemuruh tumbukan tanah dari beratus - ratus tentara Belanda (NICA) dan NICA Gandeknya terdengar sampai di tempat Wijakusuma seperti seluruh desa itu roboh. Tentara Belanda (NICA) dan kaki tangannya pada wsaktu ini mencari seorang pemimpin pengacau yang disangka berada di desa ini. Berhubung tidak ditemui pemimpin pengacau tersebut, maka penduduk laki -lakinya semua dikumpulkan di balai desa. Satu persatu ditanya oleh tentara Belanda apakah ada seorang pejuang bersembunyi di desa ini. Lalu dijawabnya oleh penduduk desa tersebut dikatakan tidak ada. Merasa tidak mendapat jawaban yang memuaskan, maka penduduk laki - laki desa Sidan satu persatu dikumpulkan oleh tentara Belanda dimana selanjutnya dipukuli habis - habisan dengan batangan - batangan bambu yang masih utuh satu persatu. Selama satu hari, mulai pagi hari hingga sore hari tentara Belanda (NICA) melakukan aksi pemukulan dengan batang bambu kepada para penduduk laki - laki desa tersebut. Pada waktu ini penduduk laki - laki desa Sidan masih banyak yang belum mendapat giliran untuk dipukul oleh tentara Belanda. Akhirnya semua penduduk laki - laki dan perempuan desa Sidan yang jumlahnya kurang lebih 600 orang digiring ke pos militer Belanda di desa Pelaga (Wijakusuma., 1979: IV). Kepala desa Sidan pada waktu itu dipimpin oleh Nang 
Vol. 3, No. 2, Juli 2019, 64

Available Online at https://ejournal.warmadewa.ac.id/index.php/kulturistik DOI: dx.doi.org/10.22225/kulturistik.3.2.1194

Margi. Nang Margi memiliki postur tubuh pendek kekar, mata bulat tajam, alis lebat hitam ikut serta digiring ke pos militer Belanda di desa Pelaga. Di tempat ini penyiksaan terus dilanjutkan untuk penduduk desa Sidan yang belum mendapat giliran. Beberapa ratus orang yang sudah menjalani siksaan pemukulan dengan batang - batang bambu, satupun tidak ada diantara mereka yang mengaku bahwa ada pejuang di desanya. Ketika penduduk desa Sidan semua dipindahkan ke desa Pelaga, kondisi desa menjadi sangat sepi. Tidak ada terdengar suara apapun di desa tersebut. Wijakusuma tidak dapat menahan diri naik melihat situasi desa ini. Sambil berjalan, Wijakusuma melihat beberapa bambu banyak hancur terbelah - belah di tengah balai desa. Selanjutnya Wijakusuma masuk ke rumah Nang Gongsor, sahabatnya yang sudah berusia 75 tahun. Nang Gongsor kaget melihat kedatangan Wijakusuma dan berkata mengapa Pak keluar, turunlah lagi. Hati Wijakusuma menjadi kacau dengan penuh kesedihan. Wijakusuma berjalan ke utara, ingin mendekati pos tentara Belanda (NICA) di desa Pelaga. Di tengah perjalanan Wijakusuma berpapasan dengan kepala desa Sidan yaitu Nang Margi. Pada waktu ini Wijakusuma dalam keadaan lemas tanpa semangat. Wijakusuma melihat kepala desa Sidan tetap tenang dan kuat. Air mukanya penuh arti keteguhan jiwa, getaran suaranya tetap berat dan meyakinkan. Wijakusuma merasa malu menghadapi watak orang Bali Aga ini. Wijakusuma dan kawan - kawan lalu duduk bersama di sebuah pematang yang agak tinggi sambil berkata dengan sedih. Wijakusuma merasa cukup lama meminta nasi kepada penduduk desa disini. Sekarang saya (Wijakusuma) mau menyudahi, dan sekaligus menyudahi juga penderitaan kami selama perjuangan. Nanti malam saya (Wijakusuma) dengan 6 orang pejuang yang bersama saya ada di desa ini bermaksud akan melakukan perang puputan di pos tentara Belanda (NICA) di desa Pelaga. Itu sebagai jawaban dari perlakuan tentara Belanda terhadap penduduk desa Sidan. Dengan suara besar penuh wibawa dan keyakinan teguh Nang Margi menjawab "jangan". Tidak ada sesuatu yang terjadi di pos tentara Belanda di desa Pelaga kecuali hanya pukulan - pukulan saja. Sekalipun bambu di tepi desa Pelaga sudah habis hancur dipakai memukul rakyat, rakyat kita tidak ada berkata apa - apa satupun. Tidak ada yang merasa sakit hati rakyat di desa Sidan, apa lagi ada yang mati akibat pukulan - pukulan yang dilakukan oleh tentara Belanda (NICA). Hanya ada beberapa orang yang sedikit robek kulitnya, karena bambu yang sudah pecah - pecah dipakai memukul kembali . Pulanglah Pak, sebentar lagi semua penduduk akan pulang kembali, karena Belanda (NICA) takut akan matinya ternak - ternak di desa karena tidak sempat diberi makan. Pulanglah sekali lagi kata Nang Margi dengan kata - katanya yang terakhir. Wijakusuma berjalan kembali dengan sedih diikuti oleh Nang Margi dibelakang. Waktu Wijakusuma dan kawan - kawan harus berpisah dipertigaan jalan setapak, Nang Margi berkata lagi dengan suara seorang ayah memanjakan anaknya supaya tidak menangis lagi. Anggaplah ini tidak pernah terjadi sesuatu dengan nada menurun. Kalimat - kalimat ini terus mengggema masuk ketelinga Wijakusuma sepanjang jalan setelah meninggalkan desa Sidan. Demikian pula dengan I Dersana, salah satu pejuang yang ditangkap oleh Belanda (NICA) pada masa revolusi fisik di Bali. Belanda (NICA) sengaja memanggil masyarakat berkumpul untuk menyaksikan I Dersana ditembak. Belanda (NICA) menembak I Dersana dengan menggunakan peluru dendem. Begitu selesai menembak I Dersana dihadapan umum, Belanda (NICA) pergi begitu saja, padahal I Dersana masih hidup. I Dersana bangun kembali setelah Belanda (NICA) pergi jauh. Belanda (NICA) sengaja memanggil 
Vol. 3, No. 2, Juli 2019, 65

Available Online at https://ejournal.warmadewa.ac.id/index.php/kulturistik DOI: dx.doi.org/10.22225/kulturistik.3.2.1194

masyarakat untuk menyaksikan penembakan I Dersana dengan maksud agar rakyat merasa takut kepada Belanda dan tidak mau lagi membantu para pejuang (Pengalaman Hidup, 1984: IV).

\section{SIMPULAN}

Revolusai fisik di Bali antara pejuang melawan Belanda (NICA) yang terjadi pada tahun 1945 - 1950 karena rakyat Bali tidak sudi dijajah kembali oleh Belanda. Para pejuang bersama - sama rakyat bahu membahu dalam melawan Belanda (NICA). Pejuang menggunakan berbagai taktik dan strategi untuk mengimbangi peralatan perang Belanda yang jauh lebih modern. Dengan demikian Belanda cukup sulit untuk mengalahkan para pejuang di Bali. Untuk dapat mengalahkan para pejuang di Bali Belanda menggunakan 2 (dua) strategi yaitu cara lunak dan cara kekerasan sehingga rakyat tidak bersimpati kepada para pejuang. Dengan cara lunak Belanda (NICA) mempengaruhi rakyat dengan memberi materi seperti : memberi kain batik, rokok, uang, jajan, nasi , dan jalan jalan naik mobil. Melalui cara ini Belanda kelihatan dermawan dan baik kepada rakyat sehingga mereka mendapat simpati.. Umumnya yang dibantu oleh Belanda adalah masyarakat yang ekonominya kurang mampu dan pendidikannya rendah. Dengan cara kekerasan terutama dilakukan kepada daerah - daerah yang pro republik sehingga rakyat menjadi jera dan takut. Melalui cara ini Belanda berharap rakyat tidak lagi mau membantu para pejuang. Apabila ada pejuang yang tertangkap, Belanda sengaja memamerkan kepada masyarakat seperti : ditendang, dipukul, diseret dengan mobil, dan ditembak di hadapan rakyat. Selain itu ada pula provokasi lain yang diciptakan oleh Belanda seperti menelanjangi kaki tangannya atau tentaranya yang terbunuh dalam peperangan. Mayat - mayat ini di arak keliling kota dengan mobil truk bak terbuka yang diisukan ada pemuda yang tewas. Bagi Ibu - ibu dan bapak - bapak yang terprovokasi propaganda Belanda ini menyebabkan tergoncang jiwanya. Cara - cara yang dilakukan oleh Belanda di atas untuk mempengaruhi rakyat Bali tidaklah mudah. Terbukti antara pejuang dengan rakyat tetap bersatu sehingga revolusi fisik yang terjadi di Bali cukup lama dapat bertahan.

\section{DAFTAR PUSTAKA}

Dekker, I. N. (1980). Sejarah Revolusi Nasional. Jakarta: PN Balai Pustaka.

Hardjawiganda, R., \& (dkk.). (1982). Operasi lintas laut Banyuwangi - Bangli. Jakarta: Departemen Pertahanan Keamanan Pusat Sejarah ABRI.

Kansil, C. S. T., \& (dkk.). (n.d.). Sejarah Perjuangan Pergerakan Kebangsaan Indonesia. Jakarta: Erlangga.

Kartodirdjo, S. (1970). Beberapa Masalah Teori Dan Metodologi Sejarah. Lembaran Sejarah, (6).

Kartodirdjo, S., \& dkk. (1977). Sejarah Nasional Indonesia VI. Jakarta: PN Balai Pustaka.

Mantan Tawanan Kecil NICA, Munang Yang Kadis LLAJ Bangli. (1991). Bali Post.

Mengenang gugurnya pahlawan Maruti. (1986, November). Bali Post.

Nasution,A, H. (1977). Sekitar Perang Kemerdekaan Indonesia 2. Bandung: Angkasa.

Pendit, N. S. (1979). Bali Berjuang.

Pengalaman Hidup. (1984). Simpen AB, I Wayan. Denpasar: Bali Post. 


\section{S. Kunlturisistillk \\ KULTURISTIK JURNAL BAHASA \& BUDAYA}

Vol. 3, No. 2, Juli 2019, 66

Available Online at https://ejournal.warmadewa.ac.id/index.php/kulturistik DOI: dx.doi.org/10.22225/kulturistik.3.2.1194

Pindha, I. G. N. (1964). Gempilan Perdjuangan Physik Di Bali, Men Bolong Memanggil II. Harian Pagi Suara Indonesia.

Pindha, I. G. N. (1968). Gempilan Perjuangan Physik Di Bali, Masa - Masa Krisis XXIII.

Poerwadarminta, W. J. . (1976). Kamus Umum Bahasa Indonesia. Jakarta: PN Balai Pustaka.

Suralaga, I. (1982). Puputan Margarana.

Tirtoprodjo, S. (1963). Sejarah Revolusi Nasional Indonesia. Jakarta: PT Pembangunan.

Wijakusuma. (1979). Kisah perdjuangan gerilya di Bali (II), pulang tanpa kulit. Bali Post. 